\title{
Can family risk-factors moderate the link between psychopathy and Life-History Strategy?
}

\section{Janko Međedović1}

Institute of Criminological and Sociological Research, Belgrade, Serbia Faculty of Media and Communication, Belgrade, Serbia

\begin{abstract}
Life History Theory is an explanatory evolutionary framework which explains differences in fitness-relevant outcomes using the characteristics of the environment and individual organisms. Basically, individuals can be positioned somewhere on the r/K continuum of the Life History Strategy (LHS): a K or slow strategy represents later maturity and reproduction, a smaller number of offspring with higher investment in them, while the $r$ (or fast) strategy follows the opposite pattern. Previous research offered evidence that psychopathy can represent a trait associated with fast LHS. In the present research we examined the relations between the family risk-factors, a four-factor model of psychopathy and the LHS in a sample of male convicts $(\mathrm{N}=181)$. The results have shown that a manipulative and deceitful interpersonal style is associated with slow LHS while shallow affect and antisocial tendencies are related to fast LHS. The interactions between psychopathy and family risk-factors revealed that parental criminal behaviour enhances the relation between fast LHS and psychopathic traits, including the manipulative interpersonal style. The findings are in accordance with the Life History Theory and provide a deeper understanding of the preservation of psychopathy in contemporary populations.
\end{abstract}

Keywords: psychopathy, family risk-factors, Life History Theory

\section{Introduction}

Key concepts of Life History Theory

In order to successfully adapt to the environment, organisms must make decisions on when and how to allocate energy and resources which are limited. Biological adaptation is a complex process, mostly associated with life-time reproduction success as the best indicator of fitness (Zietsch, Kuja-Halkola, Walum, \& Verweij, 2014). However, in order to successfully

1 janko.medjedovic@fmk.edu.rs 
reproduce and bear offspring, organisms must invest in somatic growth and maintenance, survival, gaining resources and other outcomes related to fitness. Since organisms have limited resources, energy and time, the decisions related to their investment are accompanied by trade-offs: every decision that has been made has some costs and benefits (e.g. investing in individual survival means that energy cannot be allocated to reproduction). The sum of choices regarding energy and resource allocation that individuals make in their life time depicts their Life History Strategy (LHS). The evolutionary conceptual framework which analyzes Life History Strategies, their causes, dynamics and outcomes is Life History Theory (Roff, 2002).

Most authors emphasize three crucial trade-offs in LHS and all of them are related to reproduction (Del Giudice, Gangestad, \& Kaplan, 2016). The first comprises current and future reproduction: organisms may reproduce at an earlier age or delay reproduction in order to invest in growth and resources. The Second trade-off distinguishes between quality and quantity of offspring: the former one is related to lower number of offspring with higher investment in them while the latter is based on the opposite pattern. Finally, there is a trade-off between mating and parenting: after the reproduction, individual can invest energy in offspring or in the search for another mate. Based on these trade-offs, we can distinguish two basic strategies (Figueredo, Vasquez, Brumbach, Sefcek, Kirsner, \& Jacobs, 2005). Slow or K strategy is related to a later age of reproduction and smaller number of offspring with high parental effort. Fast or $r$ strategy is associated with early reproduction, followed by a large number of offspring and low parental investment. $\mathrm{K}$ and $\mathrm{r}$ are not two distinct strategies; they are opposite poles of a single dimension of the LHS. It should be noted that neither one of them is superior: both are equally successful depending on organisms' characteristics and environmental conditions. The human species is dominantly under the slow LHS; however, there are differences between individuals regarding their LHS (Figueredo, de Baca, \& Woodley, 2013).

Two main factors influence what strategy would be developed by an individual. The first one is associated with the characteristics of the organism. LHS is partially heritable (Figueredo, Vásquez, Brumbach, \& Schneider, 2004), which implies the existence of genes that influence the phenotypic development of LHS. The second factor is the environment. Harsh, unpredictable environments with scarce resources will facilitate fast LHS; in contrast, supportive, predictable environments with sufficient resources will enable the development of the slow strategy (Kogan, Cho, Simons, Allen, Beach, Simons, \& Gibbons, 2015). The studies have shown that family characteristics are an important predictor of human LHS. Individuals who grew up in families with frequent conflicts, poor parent-child relationships or 
who experienced some form of maltreatment tended to develop the fast LHS (Rickard, Frankenhuis, \& Nettle, 2014).

\section{Psychopathy and Life History Theory}

Psychopathy is a syndrome of behavioural traits consisting of the following characteristics: 1) manipulative and deceitful interpersonal style, 2) shallow and callous affect characterized by a lack of empathy, fear and guilt, 3) disinhibition and lack of impulse control and 4) antisocial and criminal behaviour (Hare, 2003). One of the most prominent models of psychopathy was proposed by Robert Hare and collaborators and in this model these four traits are labelled as Interpersonal, Affective, Lifestyle and Antisocial psychopathy features (Hare \& Neumann, 2009). Psychopathy represents a construct that has been predominantly explored in the context of criminality and forensics because it is a reliable predictor of criminal behaviour and recidivism (Leistico, Salekin, DeCoster, \& Rogers, 2008). In fact, psychopathy is related to various types of socially undesirable phenomena such as aggressiveness, violence and immorality (Međedović, 2015). It is considered to be the core of human "dark" personality traits (Međedović \& Petrović, 2015).

Recently, psychopathy has been explored in an evolutionary context, too. One of the topics regarding its evolutionary status concerns its position on the LHS continuum. Since psychopathy is characterized by disinhibition (absence of planning and establishing long-lasting goals) and affective callousness, which indicates low potential for emotional investment, researchers assumed that it represents a trait constellation associated with fast LHS (Jonason, Webster, Schmitt, Li, \& Crysel, 2012). Indeed, empirical findings confirmed this hypothesis, revealing that the key link between psychopathy and fast LHS is the association between psychopathy and short-term mating (Jonason, Koenig, \& Tost, 2010). However, there is empirical data that did not confirm this relationship. When indicators of LHS, psychopathy, risk taking and mating effort were subjected to factor analysis, the LHS markers constituted a latent factor which was distinct from psychopathy (Gladden, Figueredo, \& Jacobs, 2009). The explanation for these unequivocal results was offered by analyzing the scores on narrow psychopathy traits. When subordinate traits were analyzed, it was shown that impulsive and antisocial psychopathy traits were indicators of fast LHS while manipulative and affective characteristics represented slow LHS (McDonald, Donnellan, \& Navarrete, 2012).

\section{Goals of the present research}

The last described research highlighted the importance of taking into account the narrow traits of psychopathy. In the present research, the four- 
factor model of psychopathy (Hare, 2003) is explored and the scores of all four traits are used in the analysis. LHS is operationalized by the age of the first sexual conduct and the indicators of unrestricted sexuality. The onset of sexual activity is considered as one of the crucial indicators of LHS (Carlson, Mendle, \& Harden, 2014), while unrestricted sexuality was used as measure of fast LHS in previous research as well (Eisenberg, Campbell, MacKillop, Modi, Dang, Koji Lum, \& Wilson, 2007). Finally, it is important to notice that all of the earlier studies on the link between psychopathy and LHS failed to include environmental factors in the design. Since the environment is very important for Life History Theory, and among environmental factors family characteristics are considered as central, we also included detrimental family indicators in the analysis. As far as we are aware, there is no study that has analysed these constructs in such a design so far.

Several hypotheses can be derived from the previous data and theory. When psychopathy is considered, two competing hypotheses can be postulated: 1) all of the psychopathic traits are related to fast LHS and 2) Interpersonal and Affective characteristics are associated with slow LHS, while Lifestyle and Antisocial features are linked to fast LHS. The third hypothesis involves the environmental factors: 3) detrimental and depriving family characteristics are enhancing positive associations between psychopathy and fast LHS.

\section{Method}

\section{Sample}

The sample consisted of 181 male participants. All subjects participated on a voluntary basis. Verbal informed consent was collected from all participants. Subjects were prisoners serving their sentence in two penal institutions in Serbia. Mean age of participants was 35.7 years $(\mathrm{SD}=10.3)$. On the average, research participants finished secondary school (43\%), a smaller number of subjects had only primary education or lower (31\%) while the rest had higher education (26\%). Participants were convicted for various crimes, including the violent and non-violent offences. All participants had elementary reading skills.

\section{Measures}

The PCL-R (Hare, 2003) is used to explore psychopathy. It is based on a rating method which involves a structured interview and extracting data from the participants' prisoner files. The raters were psychologists from the Institute of Criminological and Sociological Research (four researchers, including the author of this report). The raters were mostly balanced in 
their evaluation of psychopathy (for details see: Međedović, 2015). Four psychopathy traits were measured via 18 items (Hare \& Neumann, 2009): Interpersonal $(\alpha=.70)$, Affective $(\alpha=.64)$, Lifestyle $(\alpha=.73)$ and Antisocial $(\alpha=.74)$ psychopathic features. The rating scale on PCL-R items had 3 responding scores: 0 - the participant does not exhibit rated traits/behaviours or has the opposite characteristics, 1 - the participant does exhibit rated traits or behaviours in some degree, and 2 - the participant exhibits rated traits or behaviours in a high degree.

Family risk-factors were operationalized as negative characteristics of family functioning: substance abuse, maltreatment and presence of criminal behaviour in participants' families. These data were collected from the participants' prison files. Every file contained various pieces of information about the convict, collected from the Court, social work services or prison staff. The variables were coded as binary measures, where 0 represented the absence of the examined factor in the family, while 1 represented the presence of the examined factor.

The Life History Strategy was measured by several indicators. Participants were asked to provide information about the age when they had had their first sexual conduct, to estimate the total number of sexual partners that they had had and the number of occasions in which they had cheated on their partner. The last indicator concerned the situations in which they had two or more parallel partner relationships. The specific numbers that participants provided were taken.

The interviews were held with each participant individually, with the average lasting time of an hour and fifteen minutes. After the interview, the researchers obtained the relevant information from prisoners' files.

\section{Results}

Prediction of the fast LHS by psychopathy and family-risk factors

Before we explored the relations between psychopathy, family riskfactors and LHS, we had conducted a Principal Component Analysis (PCA) on the indicators of sexual behaviour. If all of the indicators measure single construct (in this case LHS), then only one latent component must be extracted. Indeed, the results of the PCA revealed one latent dimension with an Eigenvalue of 1.62, which explained $40.37 \%$ of original indicators variance. Multiple partner relations had the highest loading on the extracted component (.80), followed by infidelity (.79), total number of sexual partners (.44) and the age of first sexual encounter (-.40). It is clear that the extracted factor depicts the fast LHS. The score of the respondents on this 
component was saved in the database and set as a criterion measure in the regression. Psychopathy traits and family risk-factors were set as predictors. The age of participants was also included in the models because its variance needed to be controlled in the analysis. A significant regression function was obtained $\left(\mathrm{R}^{2}=.15 ; \mathrm{F}=3.01 ; \mathrm{df}=8 ; \mathrm{p}<.01\right)$. The results of the regression analysis are presented in Table 1.

Table 1. Prediction of fitness measures by psychopathy and family risk-factors

\begin{tabular}{lcccc}
\hline & $\beta$ & $\mathrm{se}$ & $\mathrm{t}$ & $\mathrm{r}$ \\
\cline { 2 - 5 } Age & -.08 & .01 & -0.87 & $-.19^{*}$ \\
Crime in family & .11 & .21 & 1.38 & .15 \\
Substance abuse & .05 & .19 & 0.59 & .05 \\
Maltreatment & -.01 & .20 & -0.08 & .08 \\
Interpersonal & -.24 & .18 & $-2.60^{*}$ & -.08 \\
Affective & .22 & .18 & $2.36^{*}$ & $.19^{*}$ \\
Lifestyle & -.03 & .21 & -0.27 & $.18^{*}$ \\
Antisocial & .23 & .19 & $2.07^{*}$ & $.26^{* *}$ \\
\hline
\end{tabular}

Notes: $\beta$ - standardized regression coefficient; se - standard error of $\beta ; \mathrm{r}-$ zero order correlation between the predictor and a criterion measure; ${ }^{\star} \mathrm{p}<.05 ;{ }^{* *} \mathrm{p}<.01$

Three psychopathy traits have had independent contribution to the prediction of the fast LHS. Antisocial and Affective traits are positively associated with the criterion while the contribution of Interpersonal style is negative. The effect sizes for all three predictors are similar. Lifestyle characteristics are positively related to the criterion measure. However, when all other variables are controlled, this relation drops to zero. Neither of family-risk factors has a significant contribution to the prediction.

\section{Family risk-factors as moderators of the relation between psychopathy and LHS}

In order to evaluate the possible moderating role of the environment on the link between psychopathy and fast LHS we analyzed the interactions between psychopathy and family characteristics. Psychopathy measures were centred in zero and interactions were calculated as the products of the centred measures and binary scores of family risk-factors. Afterwards, interaction variables were entered in a new block in the regression analysis. Three statistically significant interactions were found. In the next step, psychopathy traits were dichotomized using the median score, in order to obtain graphical representations of interactions. Finally, the two-factor ANOVA SPSS procedure was used to produce graphs. The interactions obtained in the prediction of the fast LHS are presented in the following graphs. 

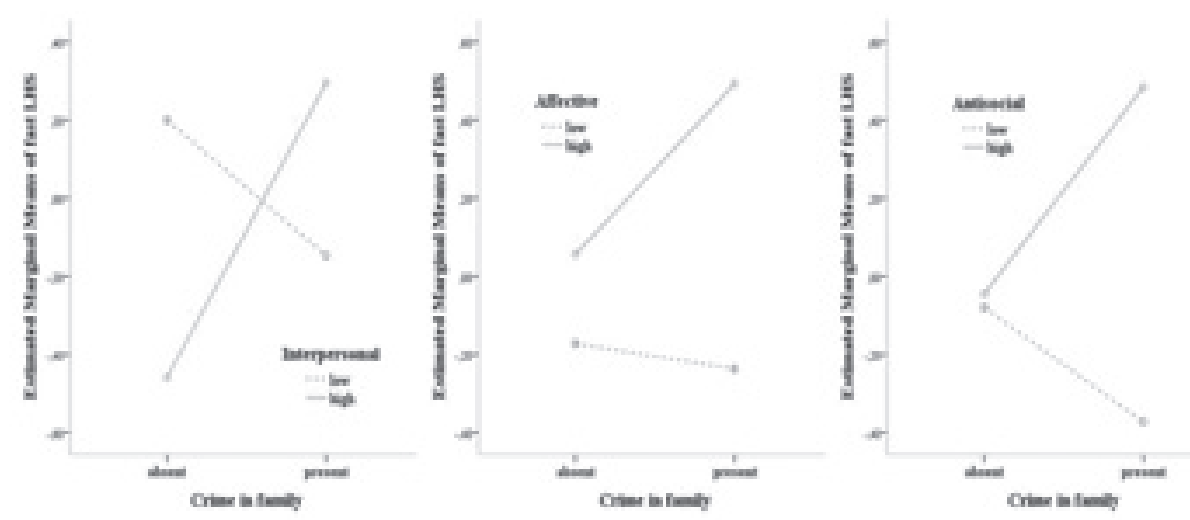

Graph 1. Interactions between parental criminal behaviour and psychopathy traits in the prediction of fast LHS

The first detected interaction (left chart) reveals the moderation which parents' criminal behaviour has on the link between psychopathic Interpersonal style and fast LHS $\left(\beta=.28, \mathrm{p}<.01 ; \Delta \mathrm{R}^{2}=.06\right)$. In the families where criminal behaviour of the parents was absent, the highest LHS scores were found in the persons with low Interpersonal style. However, in the families where this risk-factor was present, the individuals with more pronounced Interpersonal features had the fastest LHS. The second interaction (the middle chart) shows that the highest LHS scores were detected in the individuals who grew up in families where criminal behaviour was present and had highly pronounced Affective psychopathic traits $\left(\beta=.18, \mathrm{p}<.05 ; \Delta \mathrm{R}^{2}=.02\right)$. Criminal behaviour of the parents was present in the third interaction, too (the right chart). Similar to the former, the participants who grew up in the families where criminal behaviour was present and had high scores on Antisocial tendencies had the fastest LHS $\left(\beta=.25, \mathrm{p}<.01 ; \Delta \mathrm{R}^{2}=.05\right)$.

\section{Discussion}

Psychopathy traits as predictors of fast LHS

Three psychopathic traits have a positive relation with fast LHS: Lifestyle, Affective and Antisocial features. The independent contribution to the prediction of the latter two is significant. The present data is in accordance with earlier findings. Previous research showed consistent relations between psychopathic lifestyle, antisocial behaviour and fast LHS (McDonald et al., 2012). We can plausibly assume that proximate mechanisms of this relation can be reflected in the facilitated excitation and sensation seeking towards sexual stimuli (Kastner, \& Sellbom, 2012). The relation between these 
psychopathy traits and fast LHS is probably based on impulsivity, because this trait is a consistent and reliable predictor of unrestricted sexuality (Kahn, Kaplowitz, Goodman, \& Emans, 2002). The link between Affective psychopathic characteristics and fast LHS was also expected because shallow and callous affect does not enable emotional bonding which characterizes the long-lasting partner relations. Furthermore, this trait indicates dysfunctional partner relations characterized by violence, which is not impulsive but premeditated in its nature (Stanford, Houston, \& Baldridge, 2008). When all of these findings are taken into account it is not surprising that psychopathy not only facilitates fast LHS but also represents a disposition towards sexuallyrelated criminal behaviour (Hawes, Boccaccini, \& Murrie, 2013).

The only trait that deviates from the described pattern is Interpersonal style. It is associated with slow LHS. This finding partially corroborates the previous findings of McDonald and colleagues (2012). The authors explained the link between the Interpersonal features and slow LHS in the following manner: this trait is characterized by high confidence, dominance and self-esteem. These features are more prominent in slow LHS because they enable acquirement of resources and social status, which in turn delays reproduction. The findings that these traits correlate positively with achievement motives and dispositions (Ross \& Rausch, 2001) further corroborate this line of reasoning.

\section{Detrimental family factors enhance the link between psychopathy and fast LHS}

Although we can agree with the argumentation that Interpersonal features are indicators of slow LHS, the obtained interactions revealed that psychopathy traits are associated with fast LHS if detrimental factors are present in participants' families. This applies to Interpersonal psychopathy features, too. When risk-factors are absent, Interpersonal style is negatively associated with fast LHS; however, in participants with parental criminal behaviour this association changes direction. All of the detected interactions have confirmed the basic assumption of Life History Theory: scarce, unpredictable and stressful environments enable the development of fast LHS. A manipulative and deceitful interpersonal style can be related both to the fast and slow LHS, depending on the presence of parental criminal behaviour. Shallow and callous affect is basically related to the fast LHS, but this relation is enhanced in criminogenic families. The same can be said for Antisocial and criminal behaviour. The findings from the present study join the large amount of data which show that various detrimental family factors serve as environmental triggers for the development of the fast LHS (Carlson, Mendle, \& Harden, 2014; Rickard et al., 2014).

It is important to underline that of all family risk-factors examined in the present study, criminal behaviour of the parents proved to be the most 
powerful moderator of the association between psychopathy and the fast LHS. Previous data also revealed the links between criminal behaviour and the fast LHS (Yao, Långström, Temrin, \& Walum, 2014), especially in lifecourse persistent offending (Boutwell, Barnes, Deaton, \& Beaver, 2013). Since LHS is in part heritable (Figueredo et al., 2004) it does not surprise that individuals with parental criminal behaviour exhibit fast LHS. However, the data obtained in the present research suggest that criminal behaviour within the family does not predict fast LHS directly but indirectly, by interacting with the psychopathic characteristics of individuals.

\section{Concluding remarks}

Present data corroborate and deepen the existing knowledge about the connection between psychopathy and LHS. Evidence suggests that psychopathy is a fast Life History trait. It seems that a manipulative interpersonal style is related to slow LHS, thus confirming the possibility that narrow psychopathy traits can represent different Life History Strategies (McDonald et al., 2012), which is in accordance with the first proposed hypothesis. However, when detrimental family conditions are present, even this trait facilitates the development of fast LHS. This result shows that all psychopathy traits could be associated with fast LHS, at least under certain conditions, which corroborates the second hypothesis. These findings suggest that the first and second hypotheses are in fact not mutually exclusive. Both of them can describe empirical data adequately, depending on the environmental factors. Detected interactions confirmed the third hypothesis: the presence of risk-factors in the family enhances the positive connection between psychopathy and fast LHS.

The findings from the present research have contributed to our understanding of how psychopathy is maintained in contemporary human populations. Individuals with pronounced psychopathy have a distinctive sexual strategy: the one which is based on earlier onset of sexual activity, frequent changing of partners and low investment in the relationship. This strategy could lead to earlier reproduction - a hypothesis which has recently been empirically confirmed (Međedović, Petrović, Želeskov-Đorić, \& Savić, 2015). These findings are not only of theoretical significance, but also deepen our understanding of psychopathy in an evolutionary context and contribute to the knowledge of why psychopathic individuals engage in sexually-related crimes and partner violence: it may be the result of the dysfunctional aspects of fast LHS.

The present research has several limitations. The age of the first sexual conduct and unrestricted sexual behaviour are only some of many operationalizations of the fast LHS. Obtained findings should be replicated using other measures of LHS. Family risk-factors in the present research were measured by binary indicators, which did not allow for a more precise distinction between them 
(e.g. physical or verbal maltreatment; alcohol or drug abuse, etc). Measuring family-factors in a more precise manner could provide more detailed data of the link between family dysfunction, psychopathy and LHS. Future research should pay attention not only to family factors but to other indicators of a depriving, uncertain environment which could interact with psychopathy in the prediction of LHS (e.g. poverty, social exclusion etc). Finally, the present data were obtained on the convicts' sample, which limits their generalizability. The examination of the relations between the environment, psychopathy and LHS in the general population would be fruitful.

Acknowledgments. The data described in this manuscript is the part of a larger research project. The research was financed by the Serbian Ministry of Education, Science and Technological Development within the project 47011 "Crime in Serbia: Phenomenology, risks and possibilities of social intervention". The author would like to express his gratitude to his colleagues Boban Petrović, Jelena Želeskov-Đorić and Maja Savić who participated in data collection.

\section{References}

Boutwell, B. B., Barnes, J. C., Deaton, R., \& Beaver, K. M. (2013). On the evolutionary origins of life-course persistent offending: A theoretical scaffold for Moffitt's developmental taxonomy. Journal of theoretical biology, 322, 72-80. http://dx.doi. org/10.1016/j.jtbi.2013.01.005

Carlson, M. D., Mendle, J., \& Harden, K. P. (2014). Early adverse environments and genetic influences on age at first sex: Evidence for genex environment interaction. Developmental psychology, 50(5), 1532-1542. http://dx.doi.org/10.1037/a0035479

Del Giudice, M., Gangestad, S. W., \& Kaplan, H. S. (2016). Life history theory and evolutionary psychology. In D. M. Buss (Ed.), The handbook of evolutionary psychology (2nd ed.), pp. 88-114. New York: Wiley.

Eisenberg, D.T.A., Campbell, B., MacKillop, J., Modi, M., Dang, D., Koji Lum, J., \& Wilson, D.S. (2007). Polymorphisms in the dopamine D4 and D2 receptor genes and reproductive and sexual behaviors. Evolutionary Psychology, 5(4),696-715.

Figueredo, A. J., de Baca, T. C., \& Woodley, M. A. (2013). The measurement of human life history strategy. Personality and Individual Differences, 55(3), 251-255. http://dx.doi.org/10.1037/a0033772

Figueredo, A. J., Vasquez, G., Brumbach, B. H., Sefcek, J. A., Kirsner, B. R., \& Jacobs, W. J. (2005). The K factor: Individual differences in life history strategy. Personality and Individual Differences, 39(8), 1349-1360. http://dx.doi.org/10.1016/j. paid.2005.06.009.

Figueredo, A. J., Vásquez, G., Brumbach, B. H., \& Schneider, S. M. R. (2004). The heritability of life history strategy: The K-factor, covitality, and personality. Social Biology, 51(3-4), 121-143. doi: 10.1080/19485565.2004.9989090

Gladden, P. R., Figueredo, A. J., \& Jacobs, W. J. (2009). Life history strategy, psychopathic attitudes, personality, and general intelligence. Personality and Individual Differences, 46(3), 270-275. doi:10.1016/j.paid.2008.10.010 
Hare, R. D. (2003). The Hare Psychopathy Checklist-Revised, 2nd edition. Toronto, ON, Canada: Multi-Health Systems.

Hare, R. D., \& Neumann, C. S. (2009). Psychopathy and its measurement. In P. J. Corr \& G. Matthews (Eds): Cambridge handbook of personality psychology (pp. 660-686). Cambridge: Cambridge University Press.

Hawes, S. W., Boccaccini, M. T., \& Murrie, D. C. (2013). Psychopathy and the combination of psychopathy and sexual deviance as predictors of sexual recidivism: Meta-analytic findings using the Psychopathy Checklist-Revised. Psychological assessment, 25(1), 233-243. doi: 10.1037/a0030391

Jonason, P. K., Koenig, B. L., \& Tost, J. (2010). Living a fast life. Human Nature, 21(4), 428-442. doi: 10.1007/s12110-010-9102-4

Jonason, P. K., Webster, G. D., Schmitt, D. P., Li, N. P., \& Crysel, L. (2012). The antihero in popular culture: Life history theory and the dark triad personality traits. Review of General Psychology, 16(2), 192-199. http://dx.doi.org/10.1037/a0027914

Kahn, J. A., Kaplowitz, R. A., Goodman, E., \& Emans, S. J. (2002). The association between impulsiveness and sexual risk behaviors in adolescent and young adult women. Journal of Adolescent Health, 30(4), 229-232. doi:10.1016/S1054-139X(01)00391-3

Kastner, R. M., \& Sellbom, M. (2012). Hypersexuality in college students: the role of psychopathy. Personality and Individual Differences, 53, 644-649. doi:10.1016/j. paid.2012.05.005

Kogan, S. M., Cho, J., Simons, L. G., Allen, K. A., Beach, S. R., Simons, R. L., \& Gibbons, F. X. (2015). Pubertal timing and sexual risk behaviors among rural African American male youth: Testing a Model Based on Life History Theory. Archives of sexual behavior, 44(3), 609-618. doi: 10.1007/s10508-014-0410-3

Leistico, A. R., Salekin, R. T., DeCoster, J., \& Rogers, R. (2008). A large-scale metaanalysis relating the Hare measures of psychopathy to antisocial conduct. Law and Human Behavior, 32 (1), 28 - 45. http://dx.doi.org/10.1007/s10979-007-9096-6

McDonald, M. M., Donnellan, M. B., \& Navarrete, C. D. (2012). A life history approach to understanding the Dark Triad. Personality and Individual Differences, 52(5), 601-605. doi:10.1016/j.paid.2011.12.003

Međedović, J. (2015). Nomološka mreža psihopatije [Nomological network of psychopathy]. Beograd: Institut za kriminološka i sociološka istraživanja.

Međedović, J. \& Petrović, B. (2015). The Dark Tetrad: Structural properties and location in the personality space. Journal of Individual Differences, 36(4), 228-236. doi: $10.1027 / 1614-0001 / a 000179$

Međedović, J., Petrović, B., Želeskov-Đorić, J., \& Savić, M. (2015). Psihopatija i adaptivna vrijednost: podaci iz osuđeničke populacije [Psychopathy and fitness: the data from convicts' population]. 22. Dani Ramira i Zorana Bujasa, 16-18 april, Zagreb, Hrvatska, Sažeci priopćenja, pp. 168.

Rickard, I. J., Frankenhuis, W. E., \& Nettle, D. (2014). Why are childhood family factors associated with timing of maturation? A role for internal prediction. Perspectives on Psychological Science, 9(1), 3-15. doi: 10.1177/1745691613513467

Ross, S. R., \& Rausch, M. K. (2001). Psychopathic attributes and achievement dispositions in a college sample. Personality and Individual Differences, 30(3), 471-480. doi:10.1016/S0191-8869(00)00038-6 
Stanford, M. S., Houston, R. J., \& Baldridge, R. M. (2008). Comparison of impulsive and premeditated perpetrators of intimate partner violence. Behavioral sciences \& the law, 26(6), 709-722. doi: 10.1002/bsl.808

Roff, D. A. (2002). Life history evolution. Sunderland, MA, USA: Sinauer Associates, Inc.

Yao, S., Långström, N., Temrin, H., \& Walum, H. (2014). Criminal offending as part of an alternative reproductive strategy: investigating evolutionary hypotheses using Swedish total population data. Evolution and Human Behavior, 35(6), 481488. doi:10.1016/j.evolhumbehav.2014.06.007

Zietsch, B. P., Kuja-Halkola, R., Walum, H., \& Verweij, K. J. (2014). Perfect genetic correlation between number of offspring and grandoffspring in an industrialized human population. Proceedings of the National Academy of Sciences(3), 111, 10321036. doi: 10.1073/pnas.1310058111

\section{Mogu li porodični riziko-faktori moderirati vezu između psihopatije i Strategije Životne Istorije?}

\section{Janko Međedović}

Institut za kriminološka i sociološka istraživanja, Beograd, Srbija

Fakultet za medije i komunikacije, Beograd, Srbija

Teorija Životne Istorije je eksplanatorni teorijski okvir koji objašnjava razlike u adaptivnoj vrednosti koristeći karakteristike sredine i jedinki koje u njoj žive. Teorija predviđa da se pojedinci mogu pozicioniranti negde na $\mathrm{r} / \mathrm{K}$ kontinuumu Strategija Životne Istorije (SŽI): K ili spora strategija se zasniva na kasnijem sazrevanju i reprodukciji, manjem broju potomaka s povećanim ulaganjem u njih, dok r (ili brza) strategija prati obrnuti obrazac. Prethodna istraživanja ponudila su dokaze koji upućuju da psihopatija može predstavljati crtu povezanu s brzom SŽI. U ovom istraživanju ispitan je odnos između porodičnih riziko-faktora, četvorofaktorskog modela psihopatije i SŽI na uzorku osuđenih lica muškog pola $(\mathrm{N}=181)$. Rezultati su pokazali kako je manipulativni i prevrtljivi interpersonalni stil povezan sa sporom, dok su površni afekt i antisocijalne tendencije povezane s brzom SŽI. Interakcije između psihopatije i porodičnih riziko-faktora pokazale su da prisustvo kriminalnog ponašanja kod roditelja pojačava odnos između psihopatskih crta i brze SŽI, uključujući i manipulativni interpersonalni stil. Nalazi ovog istraživanja u skladu su s Teorijom Životne Istorije i nude dublje razumevanje mehanizama održavanja psihopatije u savremenim populacijama.

Ključne reči: psihopatija, porodični riziko-faktori, Teorija Životne Istorije 